\title{
A thermodynamic model for hydrous silicate melts in the system $\mathrm{NaAlSi}_{3} \mathrm{O}_{8}-\mathrm{KAlSi}_{3} \mathrm{O}_{8}-\mathrm{Si}_{4} \mathrm{O}_{8}-\mathrm{H}_{2} \mathrm{O}$
}

\author{
Marcus Kirschen' and Michel Pichavant
}

Centre National de Recherche Scientifique, Centre de Recherches sur la Synthèse et la Chimie des Minéraux CRSCM, 1A rue de la Férollerie, F-45071 Orléans Cedex 2, France - remplacé par UMR6113 - ISTO

\section{Abstract}

Computation of crystal-liquid equilibria in hydrous silicate systems requires a model of the free energy of the hydrous liquid that defines the activity of the melt components at given temperature, pressure and composition. We present in this study a parametrization of the free energy of the liquid in the haplogranite system $\mathrm{NaAlSi}_{3} \mathrm{O}_{8}-\mathrm{KAlSi}_{3} \mathrm{O}_{8}-\mathrm{Si}_{4} \mathrm{O}_{8}-\mathrm{H}_{2} \mathrm{O}$ based on the Margules approach. The excess free energy of the multicomponent melt is approximated from the binaries with the Kohler extrapolation method. Model parameters have been fitted to phase equilibrium data by mathematical programming techniques. A small but complex excess function of the anhydrous melt composition is necessary to reproduce reported liquidus phase relations. Using partial molar $C_{\mathrm{p}}$ data from the literature for the $\mathrm{H}_{2} \mathrm{O}$ melt component and a simple polynomial approximation for the molar volume, standard state enthalpy and entropy were refined close to $-287 \mathrm{~kJ} / \mathrm{mol}$ and $67.2 \mathrm{~J} / \mathrm{K}$ mol, respectively. Calculated crystalliquid phase relations are in good agreement with measurements to $5 \mathrm{kbar}$, and the modelled melt-fluid coexistence surface yields a valuable first order approximation of the $\mathrm{H}_{2} \mathrm{O}$ solubility at near liquidus temperatures. Thermodynamic assessment of solubility and liquidus data suggests that $\mathrm{H}_{2} \mathrm{O}$ mixing differs considerably in feldspar melts and in silica melts. $\mathrm{Si}_{4} \mathrm{O}_{8}-\mathrm{H}_{2} \mathrm{O}$ mixing contributes to a very minor degree to the haplogranite system.

Author Keywords: Haplogranite system; Hydrous silicate melt; Liquidus phase equilibria; Linear programming 


\section{Introduction}

The influence of $\mathrm{H}_{2} \mathrm{O}$ on melting and crystallization temperatures of silicic magmas has been for decades an attractive research topic in geosciences since the pioneering studies from Goranson and Goranson, Bowen and Tuttle (1950) and Tuttle and Bowen (1958) at high pressures and under $\mathrm{H}_{2} \mathrm{O}$-saturated conditions. The haplogranite system $\mathrm{NaAlSi}_{3} \mathrm{O}_{8}(\mathrm{ab})$ $\mathrm{KAlSi}_{3} \mathrm{O}_{8}$ (or) $-\mathrm{Si}_{4} \mathrm{O}_{8}$ (qtz) $-\mathrm{H}_{2} \mathrm{O}$ has been widely accepted as an analogue for a broad range of natural silicic magmas. More recently, liquidus phase equilibria were determined at high pressures and for $\mathrm{H}_{2} \mathrm{O}$-undersaturated conditions in order to distinguish the effects of pressure and $\mathrm{H}_{2} \mathrm{O}$ activity on phase relations in the haplogranite system (Steiner, 1970; Fenn, 1973; Holtz; Pichavant and Becker). Analytical techniques were significantly improved, too, allowing the $\mathrm{H}_{2} \mathrm{O}$ content of the quench glasses to be precisely measured by infrared spectroscopy and Karl Fischer titration (KFT) (e.g. Behrens and Behrens). This extensive experimental database provides an excellent tool to test and to develop existing thermodynamic models of hydrous silicate melts. Presently, few thermodynamic models exist for multicomponent hydrous silicate melts (e.g. Nekvasil; Blencoe; Ghiorso and Wen). The scope of the present study is the derivation of a thermodynamic model for hydrous silicate melts that is consistent with the available liquidus data in the haplogranite system within experimental uncertainty. The aim of such a model is the intra- and extrapolation of the experimentally determined liquidus phase equilibria for pressures up to $10 \mathrm{kbar}$ and especially for $\mathrm{H}_{2} \mathrm{O}$-undersaturated conditions to provide a working tool applicable to most silicic magmas. Computation of phase equilibria requires an expression of the free energy of the melt as function of temperature, pressure and composition. In Section 1, we will present a parametrization of the Gibbs free energy of the melt based on the Margules approach and the computational method we used to derive an internally consistent set of solution parameters. In Section 2, model results of this study will be presented and compared with those of existing models of hydrous melts.

\section{Parametrization of the Gibbs free energy of the melt}

Burnham (1974) observed that the compositional dependence of $\mathrm{H}_{2} \mathrm{O}$ fugacity in felsic melts is greatly simplified when the anhydrous composition is normalized to eight oxygens. As a consequence of this normalization, the partial molar volumes of the anhydrous mixing units assume approximately equal values and the free energy of mixing is close to ideal. In order to describe the mixing behaviour with minimum model parameters and maximum reliability, we used $\mathrm{NaAlSi}_{3} \mathrm{O}_{8}, \mathrm{KAlSi}_{3} \mathrm{O}_{8}$ and $\mathrm{Si}_{4} \mathrm{O}_{8}$ as endmembers of the anhydrous melt for two reasons. First, we avoid higher order excess parameters in the molar excess Gibbs free energy $\left(G^{\mathrm{xs}}\right)$ arising from inadequately chosen mixing components, and, second, thermodynamic properties of pure albite, orthoclase and silica melts are well constrained by experimental data at ambient and high pressure. $\mathrm{H}_{2} \mathrm{O}$ was added as hypothetical oxide endmember of the hydrous melt. This approach is based on the assumption that the free energy of $\mathrm{H}_{2} \mathrm{O}$ dissociation in silicate melts is negligible compared with changes of the bulk free energy as function of total $\mathrm{H}_{2} \mathrm{O}$ content of the melt.

We adopted a pressure- and temperature-independent Margules-type excess polynomial to fit the remaining non-ideal mixing of the melt components in the six binary systems. Due to lack of experimental evidence, there is neither excess entropy, nor excess heat capacity, nor excess volume in the present formulation. The absence of these parameters has the advantage of a fairly stable extrapolation of $G^{\text {mix }}$ in $P$ and $T$ outside the calibration range. We used three 
excess parameters for the anhydrous binary melts to account for a small but complex excess heat of mixing as measured in-situ for ab-or melts by Knudsen cell mass spectroscopy (Fraser and Bottinga, 1985). We found three $P, T$-independent Margules parameters necessary to fit reported liquidus data in the binary systems ab- $\mathrm{H}_{2} \mathrm{O}$ (Fenn, 1973) and qtz- $\mathrm{H}_{2} \mathrm{O}$ (Kennedy et al., 1962), i.e. $G^{\mathrm{xs}}=x_{1} x_{2} \cdot\left[W_{1112} x_{1}^{2}+W_{1122} x_{1} x_{2}+W_{1222} x_{2}^{2}\right]$ with the same polynomial degree, 4 , as used by Clemens and Navrotsky $(1987)$ to fit measured $H^{\text {mix }}\left(\mathrm{ab}-\mathrm{H}_{2} \mathrm{O}\right)$. The same excess polynomial was adapted to or $-\mathrm{H}_{2} \mathrm{O}$ for symmetry reasons.

The ternary and quaternary excess heat of mixing was approximated from binary excess terms using a Kohler-type extrapolation method (Kohler and DeCapitani). We prefer the Kohler approach in this study because (1) the addition of numerous excess parameters is avoided in the higher order systems, (2) there is no experimental evidence suggesting additional strong ternary and quaternary interaction in order to justify additional higher order excess terms, (3) this appears promising in the perspective of an extension of the model to more complex systems (e.g. anorthite-bearing melts) and (4) in order to tightly constrain the binary excess parameters with binary, ternary, and quaternary data.

Therefore, the molar Gibbs free energy of formation $(G)$ of the hydrous haplogranite melt is approximated with:

$$
G_{\mathrm{melt}}=\sum_{i} x_{i}\left[\mu_{i}^{0}+R T \ln \left(x_{i}\right)\right]+G^{\mathrm{ss}},
$$

where the summation is taken over all melt components ab, or, qtz, and $\mathrm{H}_{2} \mathrm{O} ; \mu_{i}^{0}(P, T)$ being the chemical potential of pure component $i$ :

$\mu_{i}^{0}(P, T)=\Delta_{\mathrm{f}} H_{i}^{0}-T S_{i}^{0}+\int C_{\mathrm{p} i}(T) \mathrm{d} T-T \int\left[C_{\mathrm{p} i}(T) / T\right] \mathrm{d} T+\int V_{i}(P, T) \mathrm{d} P$

( $\Delta_{\mathrm{f}} H_{i}^{0}$ being the molar enthalpy of formation from the constituent stable elements at $T_{0}=298.15 \mathrm{~K}$ and $P_{0}=10^{5} \mathrm{~Pa}, S_{i}^{0}$ the standard molar entropy, $C_{p i}$ the molar heat capacities, $V_{i}$ molar volumes) and $G^{\mathrm{xs}}$ the integral molar excess heat of mixing:

$G^{\mathrm{xs}}=\sum x_{i} x_{j}\left(x_{i}+x_{j}\right)^{-k}\left[W_{i i i j} x_{i}^{2}+W_{i i j j} x_{i} x_{j}+W_{i j j j} x_{j}^{2}\right]$.

The summation is taken over all binary systems, $W$ being the binary Margules parameters, $x$ are mole fractions, $k=2$ for the Kohler extrapolation (see DeCapitani and Kirschen, 1998, for details and for computation of $R T \ln \left(\gamma_{i}\right)$ from $\left.G^{\mathrm{xs}}\right)$.

The $P, T$-dependence of the liquid volumes was approximated by a series polynomial as used by (Berman, 1988):

$$
V_{\text {liq }, i}(T, P)=V^{0}\left[1+v_{1}\left(T-T_{0}\right)+v_{2}\left(T-T_{0}\right)^{2}+v_{3}\left(P-P_{0}\right)+v_{4}\left(P-P_{0}\right)^{2}\right] .
$$

This approach is considered a first order approximation of $\left(\partial G_{\text {melt }} / \partial P\right)_{T}$ for the purpose of this study because experimental ab and qtz liquidus data are reproduced, at least, to $15 \mathrm{kbar}$ at dry conditions and to $5 \mathrm{kbar}$ in the hydrous system. An extrapolation of the present formulation to higher pressure is difficult as complete fluid-melt miscibility is observed above $10 \mathrm{kbar}$ in the $\mathrm{SiO}_{2}-\mathrm{H}_{2} \mathrm{O}$ binary system (Kennedy et al., 1962; see also Goldsmith and Shen, for ab- $\mathrm{H}_{2} \mathrm{O}$ system). Critical mixing behaviour is, in principal, poorly modelled with two distinct equations of state for the melt and for the fluid phase. The development of a thermodynamic 
model that correctly describes critical fluid-melt mixing behaviour lies outside the scope of this paper.

\section{Optimization of the model parameters}

Model parameters were fitted to phase equilibrium data with mathematical programming techniques. This method was introduced to thermochemical analysis by Gordon (1973) and applied to Margules-type excess parameters by Berman and Brown (1984). Advantages and disadvantages of this optimization technique and least squares refinement have been widely discussed (e.g. Berman and Powell). The strategy as applied to hydrous melts in this study is briefly described here:

Points on the liquidus surface are determined within a certain accuracy in temperature, pressure and composition by at least two experiments, thus defining a bracket on the actual equilibrium state (where the free energy of reaction LIQUID $=$ solid, $\Delta_{\mathrm{r}} G$, equals 0 ). Two corresponding half brackets are characterized with $\Delta_{\mathrm{r}} G<0$ ("liquid stable") and $\Delta_{\mathrm{r}} G>0$ ("solid stable"). For the melting of a crystalline phase, this relation is converted to:

$$
\sum_{i} x_{i}\left[\mu_{i}^{0}+R T \ln \left(a_{i}\right)\right]-G_{\mathrm{s}}<\text { or }>0
$$

where $x_{i}$ is the mole fraction, $a_{i}$ the activity of melt component $i, \mu_{i}^{0}(P, T)$ from Eq. (2) and $G_{\mathrm{s}}(P, T)$ is the free energy of formation of the solid. Each phase equilibrium experiment defines, at least, one constraint to $G_{\text {melt }}$; however, some of them are redundant. These constraints are graphically represented in Fig. 1. In the present formulation, relations (5) are linear in decision variables. Then, the optimization problem is linearly constrained and can be readily solved by large-scale linear programming methods. In evaluating a large set of linear constraints, linear programming has the advantage to yield a solution in a finite number of steps, giving a feasible solution that is consistent with all experimental half brackets. We used the software package MINOS 5.5 (Murtagh and Saunders, 1998) to prove the feasibility of the set of constraints and to solve the optimization comprising 36 variables and 496 linear constraints in the final run. $\Delta_{\mathrm{f}} H^{0}, S^{0},(\partial V / \partial P)_{T}$ of the melt endmembers, and the excess parameters $W$ were used as fit variables. Once a feasible solution has been obtained, a selection criterion or objective function is required to define and find a unique "best" solution. We defined the objective function in order to minimize the difference between calculated and measured heats of fusion by least-squares methods.

For the crystalline phases, we applied thermochemical parameters from the updated TWQ database (Berman and Aranovich, 1996). Mixing properties of the feldspars were taken from Elkins and Grove (1990). $\mathrm{H}_{2} \mathrm{O}$ and $\mathrm{SiO}_{2}$ solution in the feldspars was neglected and we assumed pure silica polymorphs. To further constrain $\mu_{i}^{0}$ of melt components, we used reported $C_{\mathrm{p}}$ and $\Delta H_{\text {fus }}$ data from Richet and Bottinga (1986) and $C_{\mathrm{pH} 2 \mathrm{O}}$ from Richet (1987) as first estimate. Liquid volume parameters $V^{0}$ and $v_{1}$ were taken from Knoche et al. (1995), $v_{3}$ and $v_{4}$ were fitted to experimental data. 


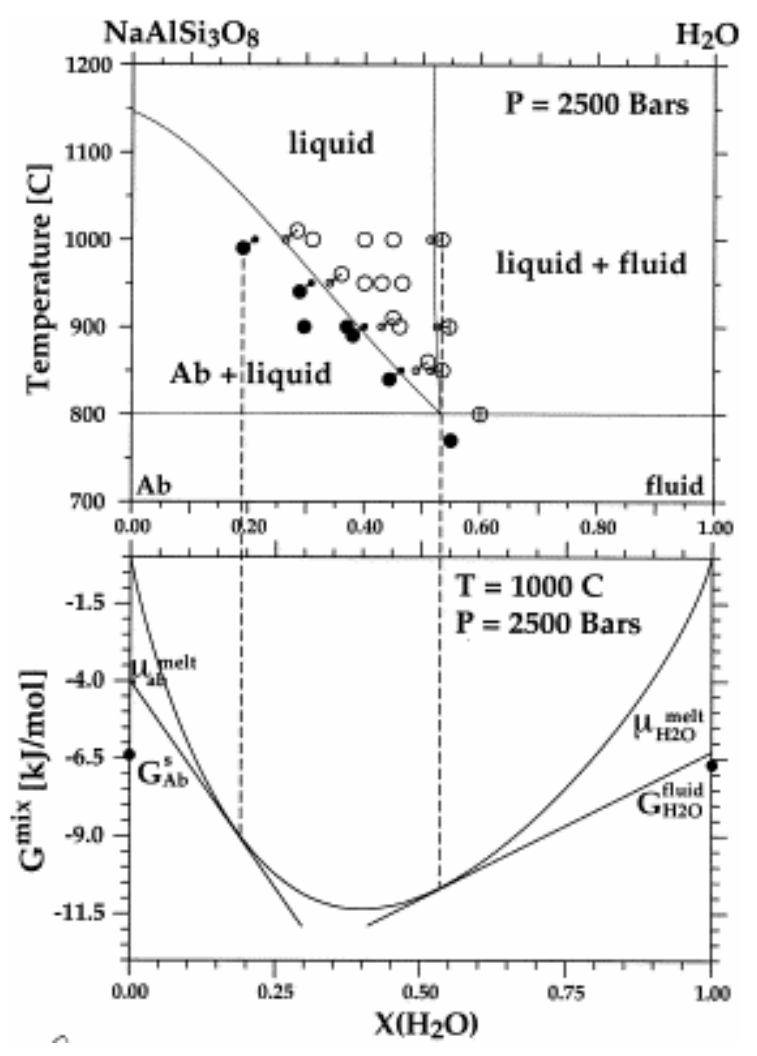

Fig. 1. Assessment of quench experiments in the system $\mathrm{NaAlSi}_{3} \mathrm{O}_{8}-\mathrm{H}_{2} \mathrm{O}$. Symbols point to quench of albite+liquid (•), one liquid (०) and liquid+fluid phase (slashed open circles) from Fenn (1973). Calculated stability field boundaries are from this study. Constraints are relaxed to account for experimental uncertainty $\left( \pm 10^{\circ} \mathrm{C}\right.$ and $\left.2 \mathrm{~mol} \% \mathrm{H}_{2} \mathrm{O}\right)$. Each experiment yields at least one inequality constraint to the free energy of the hydrous melt with respect to the free energy of albite or fluid.

Solution parameters were fitted to phase equilibrium data in the endmember systems $\mathrm{NaAlSi}_{3} \mathrm{O}_{8}$ (Boettcher et al., 1982), $\mathrm{KAlSi}_{3} \mathrm{O}_{8}$ (Lindsley and Boettcher), $\mathrm{SiO}_{2}$ (Hudon, 1998), and in the hydrous systems, $\mathrm{NaAlSi}_{3} \mathrm{O}_{8}-\mathrm{KAlSi}_{3} \mathrm{O}_{8}-\mathrm{H}_{2} \mathrm{O}$ (Fenn, 1973), and $\mathrm{NaAlSi}_{3} \mathrm{O}_{8}-$ $\mathrm{KAlSi}_{3} \mathrm{O}_{8}-\mathrm{SiO}_{2}-\mathrm{H}_{2} \mathrm{O}$ (Steiner, 1970; Holtz; Pichavant and Becker). We preferred these data in the optimization of the hydrous melt parameters because (1) experiments were performed at both $\mathrm{H}_{2} \mathrm{O}$-saturated and -undersaturated conditions and (2) the $\mathrm{H}_{2} \mathrm{O}$ content of the melt is reasonably well known (determined either from the $\mathrm{H}_{2} \mathrm{O}$ content of the bulk charge or from the KFT analysis of the quenched glasses). Additional constraints below 6 kbar stem from $\mathrm{H}_{2} \mathrm{O}$-saturated melting experiments in the systems $\mathrm{SiO}_{2}-\mathrm{H}_{2} \mathrm{O}$ (Kennedy et al., 1962), $\mathrm{NaAlSi}_{3} \mathrm{O}_{8}-\mathrm{H}_{2} \mathrm{O}$ (Goldsmith and Jenkins, 1985), and $\mathrm{KAlSi}_{3} \mathrm{O}_{8}-\mathrm{H}_{2} \mathrm{O}$ (Goldsmith and Peterson, 1990). Water contents of the quenched glasses were taken from Holtz; Holtz and Holtz, Behrens (1995), and Behrens at al. (2000). Solubilities at $1100^{\circ} \mathrm{C}$ from Kennedy et al. (1962) determined with the weight loss method were substituted by KFT data from Holtz et al. (2000). Variation of $\mathrm{H}_{2} \mathrm{O}$ solubility was assumed to be less than \pm 0.2 wt.\% when extrapolated from $1200^{\circ} \mathrm{C}$ to $1100^{\circ} \mathrm{C}$ below 4 kbar. All halfbrackets were relaxed by considering conservative overall experimental uncertainties in temperature $\left( \pm 15^{\circ} \mathrm{C}\right.$ for experiments at $1000^{\circ} \mathrm{C}$ from Steiner $(1970), \pm 10^{\circ} \mathrm{C}$ else $)$ and composition $( \pm 2 \mathrm{~mol} \%)$.

As $\mathrm{H}_{2} \mathrm{O}$ solubility in the crystalline phases is neglected, $\Delta H_{\text {fus }}$ measurements and liquidus data constrain the chemical potentials of ab, or, and qtz in the melt (i.e. $H^{0}, S^{0}, v_{3}$, and $v_{4}$, and $W$ ), but not the chemical potential of the $\mathrm{H}_{2} \mathrm{O}$ melt component, $\mu_{\mathrm{H} 2 \mathrm{O}}=\mu_{\mathrm{H} 2 \mathrm{O}}{ }^{0}+R T \ln \left(a_{\mathrm{H} 2 \mathrm{O}}\right)$. In order to estimate the chemical potential of pure $\mathrm{H}_{2} \mathrm{O}$ melt $\left(\mu_{\mathrm{H} 2 \mathrm{O}}{ }^{0}\right)$, we used $\mathrm{H}_{2} \mathrm{O}$ solubility data as 
additional constraints below $3 \mathrm{kbar}$ and $1200^{\circ} \mathrm{C}$ (see Fig. 1). The merit of these constraints on $\mu_{\mathrm{H} 2 \mathrm{O}}{ }^{0}$ increases as the $\mathrm{H}_{2} \mathrm{O}$ activity in the melt is fixed by liquidus constraints through the Gibbs-Duhem relation. Due to the large experimental database in the haplogranite system and the fairly stable excess function, this approach is therefore justified. The free energy of the supercritical fluid, $G_{\mathrm{s}}$ in Eq. (5), was approximated with the Haar et al. (1984) equation of state. Neglect of melt dissolution in the fluid (e.g. $2.4 \mathrm{~mol} \%$ qtz at $1080^{\circ} \mathrm{C}, 3.0 \mathrm{kbar}$, Kennedy et al., 1962) leads to an estimated error to $\mu_{\mathrm{H} 2 \mathrm{O}}$ fluid of the order $R T \ln \left(x_{\mathrm{H} 2 \mathrm{O}}\right)=-270 \mathrm{~J} / \mathrm{mol}$. To avoid an erroneous reduction of the extent of the feasible region from an overestimated $G_{\text {fluid, }}$, we skipped "fluid stable" constraints above $2.5 \mathrm{kbar}$ and $1100^{\circ} \mathrm{C}$. Therefore, the $\mathrm{H}_{2} \mathrm{O}$ saturation surface is overestimated at $P>3 \mathrm{kbar}$ and $T>1100^{\circ} \mathrm{C}$ when calculated with a pure $\mathrm{H}_{2} \mathrm{O}$ fluid phase. In a subsequent step, we have to substitute the Haar et al. (1984) equation of state of pure $\mathrm{H}_{2} \mathrm{O}$ with a multicomponent solution model that incorporates dissolution of ab, or, and qtz melt components in the fluid. Such a solution model is not available at the moment. For this purpose, accurately determined fluid-melt compositions are required in addition to crystalline-fluid phase equilibrium data at elevated temperatures, e.g. Bai and Koster van Groos (1999). Direct volume measurements of $\mathrm{ab}-\mathrm{H}_{2} \mathrm{O}$ melts from Burnham and Davis (1971) were not incorporated in the present study, because they used Ca-bearing natural starting material. Due to these limitations, we do not refine additional volume terms as $V_{\text {liq }}(T, P)=\sum_{i, j} a_{i j} P^{i} T^{j}$ (Burnham and Davis, 1971) from $\mathrm{H}_{2} \mathrm{O}$ solubility data. Such refinements will significantly improve the reliability of the predicted solubility surface at supraliquidus temperature and $P>5 \mathrm{kbar}$ but it is of minor importance for liquidus phase relations of the present study.

Thermochemical parameters of crystalline and liquid oxides used in this study are given in Table 1, Table 2 and Table 3. Margules-type excess parameters are listed in Table 4. Inconsistencies between calculated and observed phase relations remain for experiments no. 413 (Kfs out), from Steiner (1970) and experiment $\left[5 \mathrm{kbar}, 820^{\circ} \mathrm{C}, x_{\mathrm{H} 2 \mathrm{O}}=0.7\right.$, glass no. $25_{5} 34_{5}$, Fsp in] from Holtz et al. (1992b). This may be a consequence of the deviation from the ab-orqtz composition plane (1) by Na contamination that affected the starting gels used by Luth et al. (1964) and Steiner (1970) as discussed in Holtz et al. (1992b) and (2) due to 1.7 normative corundum of the quenched glass (Holtz et al., 1992b).

Table 1. Standard state thermochemical properties of solid and liquid oxides

$\mathrm{H}_{2} \mathrm{O}$ fluid, see text. $T_{0}=298.15 \mathrm{~K}, P_{0}=1$ bar.

\begin{tabular}{|c|c|c|c|c|c|}
\hline & Abbreviation & Formula & $\Delta_{\mathrm{f}} H^{0}[\mathrm{~J} / \mathrm{mol}]$ & $S^{0}[\mathrm{~J} / \mathrm{K} \mathrm{mol}]$ & Reference \\
\hline$\alpha$-Cristobalite & $\alpha$-Crist & $\mathrm{SiO}_{2}$ & -907753.35 & 43.3943 & Berman (1988) \\
\hline$\beta$-Cristobalite & $\beta$-Crist & $\mathrm{SiO}_{2}$ & -906377.23 & 46.0288 & Berman (1988) \\
\hline$\alpha$-Quartz & $\alpha-Q z$ & $\mathrm{SiO}_{2}$ & -910699.95 & 41.4600 & Berman (1988) \\
\hline$\beta$-Quartz & $\beta-Q z$ & $\mathrm{SiO}_{2}$ & -908626.77 & 44.2068 & Berman (1988) \\
\hline low-Tridymite & 1-Trid & $\mathrm{SiO}_{2}$ & -907749.56 & 43.7702 & Berman (1988) \\
\hline high-Tridymite & h-Trid & $\mathrm{SiO}_{2}$ & -907045.12 & 45.5237 & Berman (1988) \\
\hline Albite & $\mathrm{Ab}$ & $\mathrm{NaAlSi}_{3} \mathrm{O}_{8}$ & -3921618.20 & 224.4120 & Berman (1988) \\
\hline K-feldspar & Kfs & $\mathrm{KAlSi}_{3} \mathrm{O}_{8}$ & -3970790.78 & 214.1451 & Berman (1988) \\
\hline $\mathrm{Ab}$ liq & $\mathrm{ab}$ & $\mathrm{NaAlSi}_{3} \mathrm{O}_{8}$ & -3903511.00 & 191.4476 & this study \\
\hline Or liq & or & $\mathrm{KAlSi}_{3} \mathrm{O}_{8}$ & -3935320.00 & 217.0192 & this study \\
\hline Qtz liq & qtz & $\mathrm{Si}_{4} \mathrm{O}_{8}$ & -3679484.00 & 71.6667 & this study \\
\hline $\mathrm{H}_{2} \mathrm{O}$ liq & $\mathrm{H}_{2} \mathrm{O}$ & $\mathrm{H}_{2} \mathrm{O}$ & -286748.50 & 67.1751 & this study \\
\hline
\end{tabular}


Table 2. Volume parameters used in this study

$V(T, P)=V_{0}\left[1+v_{1}\left(T-T_{0}\right)+v_{2}\left(T-T_{0}\right)^{2}+v_{3}\left(P-P_{0}\right)+v_{4}\left(P-P_{0}\right)^{2}\right]$ in $\mathrm{J} /$ bar, $T$ in $\mathrm{K}, P$ in bar, $T_{0}=298 \mathrm{~K}, P_{0}=1$ bar.

\begin{tabular}{lccllll}
\hline & $V_{0}[\mathrm{~J} / \mathrm{bar}]$ & $v_{1}\left[10^{5} / \mathrm{K}\right]$ & $v_{2}\left[10^{5} / \mathrm{K}^{2}\right]$ & $v_{3}\left[10^{5} / \mathrm{bar}\right]$ & $v_{4}\left[10^{8} / \mathrm{bar}^{2}\right]$ & Reference \\
\hline$\alpha$-Cristobalite & 2.587 & 2.08240619 & 0 & -0.25145068 & 0 & Berman $(1988)$ \\
$\beta$-Cristobalite & 2.730 & 0.31892080 & 0 & -0.10997269 & 0 & Berman $(1988)$ \\
$\alpha$-Quartz & 2.269 & 2.38945698 & 0 & -0.24339298 & 0.00101375 & Berman $(1988)$ \\
$\beta$-Quartz & 2.370 & 0 & 0 & -0.12382672 & 0.00070871 & Berman $(1988)$ \\
low-Tridymite & 2.675 & 1.93394983 & 0 & -0.25084238 & 0 & Berman $(1988)$ \\
high-Tridymite & 2.737 & 0.48286524 & 0 & -0.07396833 & 0.00037354 & Berman $(1988)$ \\
Albite & 10.083 & 2.63072032 & 0.00032407 & -0.19446932 & 0.00048611 & Berman $(1988)$ \\
K-feldspar & 10.869 & 1.51450750 & 0.00054850 & -0.18045110 & 0.00051120 & Berman $(1988)$ \\
Ab liq & 9.437 & 23.04500000 & 0 & -2.92533477 & 0.11517438 & this study \\
Or liq & 10.112 & 21.51100000 & 0 & -2.39792453 & 0.06287995 & this study $^{\mathrm{a}}$ \\
Qtz liq & 10.691 & 2.81800000 & 0 & -1.60660444 & 0.05337397 & this study $^{\mathrm{a}}$ \\
$\mathrm{H}_{2} \mathrm{O}$ liq & 1.200 & 56.83363333 & 0.03676951 & -0.03441358 & 1.06892250 & this study $^{\mathrm{b}}$ \\
\hline
\end{tabular}

Table 3. $C_{\mathrm{p}}$ coefficients used in this study

\begin{tabular}{|c|c|c|c|c|c|c|}
\hline & $k_{1}$ & $k_{2}$ & $k_{4}$ & $k_{3}$ & $k_{8}$ & Reference \\
\hline$\alpha$-Cristobalite & 83.5136 & 0 & -374.693 & -2455360 & 280072192 & Berman and Brown (1985) \\
\hline$\beta$-Cristobalite & 83.5136 & 0 & -374.693 & -2455360 & 280072192 & Berman and Brown (1985) \\
\hline$\alpha$-Quartz & 80.01199 & 0 & -240.276 & -3546684 & 491568384 & Berman and Brown (1985) \\
\hline$\beta$-Quartz & 80.01199 & 0 & -240.276 & -3546684 & 491568384 & Berman and Brown (1985) \\
\hline low-Tridymite & 75.3727 & 0 & 0 & -5958095 & 958246144 & Berman $(1988)^{c}$ \\
\hline high-Tridymite & 75.3727 & 0 & 0 & -5958095 & 958246144 & Berman (1988) \\
\hline Albite & 393.6357 & 0 & -2415.498 & -7892826 & 1070636032 & Berman $(1988)^{d}$ \\
\hline K-feldspar & 381.3723 & 0 & -1941.045 & -12037252 & 1836425472 & Berman and Brown (1985) \\
\hline $\mathrm{Ab}$ liq & 300.6700 & 0.042620 & 0 & 0 & 0 & Richet and Bottinga (1984) \\
\hline Or liq & 261.8400 & 0.061872 & 0 & 0 & 0 & Richet and Bottinga (1984) \\
\hline Qtz liq & 325.4920 & 0 & 0 & 0 & 0 & Richet and Bottinga (1984) \\
\hline $\mathrm{H}_{2} \mathrm{O}$ liq & 81.4370 & 0.000098 & 0 & -3109400 & 0 & Richet (1987) \\
\hline
\end{tabular}

$C_{\mathrm{p}}$ function used in this study: $C_{\mathrm{p}}=k_{1}+k_{2} T+k_{3} / T^{2}+k_{4} / \sqrt{ } T+k_{8} / T^{3}$ in $\mathrm{J} / \mathrm{K} \mathrm{mol}$.

${ }^{\mathrm{a}} \mathrm{\lambda}$ transition modelled with additional $C_{\mathrm{p}}=(T-\mathrm{d} T)[-0.14216187+0.00044142(T-\mathrm{d} T)]^{2}$ between $[298 K+\mathrm{d} T, 535 K+\mathrm{d} T]$ $\mathrm{d} T=0.048\left(P-P_{0}\right)$ (Berman and Brown, 1986)

$\lambda$ transition modelled with additional $C_{\mathrm{p}}=(T-\mathrm{d} T)[-0.09186959+0.00024607(T-\mathrm{d} T)]^{2}$ between $[373 K+\mathrm{d} T, 848 K+\mathrm{d} T]$ $\mathrm{d} T=0.023743\left(P-P_{0}\right)$ (Berman and Brown, 1986)

$\lambda$ transition modelled with additional $C_{\mathrm{p}}=(0.42670490-0.00144575)^{2}$ between $[298 \mathrm{~K}, 390 \mathrm{~K}]$ (Berman, 1988).

${ }^{\mathrm{d}} \mathrm{C} 2 / \mathrm{m}-\mathrm{C} \overline{1}$ transition modelled with Landau-type ordering parameters, (Salje, 1985).

${ }^{e} T$-dependent disordering approximated with additional $C_{\mathrm{p}}=282.98291-4831.375 / \sqrt{ } T+3620706 . / T^{2}-0.15733 T+0.00003 T^{2}$ between $[298 K, 1436 K]$, (Berman, 1988)

\section{Model results and discussion}

Reported high pressure fusion data of pure $\mathrm{SiO}_{2}$ from Jackson (1976) are not consistent with all other $\beta-\mathrm{Qz}$ melting data in the hydrous systems. Calculated melting temperatures of pure silica are $30^{\circ} \mathrm{C}$ to $50^{\circ} \mathrm{C}$ higher when projected to perfectly dry conditions. This suggests that Jackson's starting material had been contaminated before or during the run in a pyrophyllitebearing high-pressure assembly. Therefore, we used $\mathrm{SiO}_{2}$ fusion data from Hudon (1998) that were obtained using an anhydrous piston-cylinder apparatus (Hudon et al., 1994). Calculated fusion curves of pure $\mathrm{NaAlSi}_{3} \mathrm{O}_{8}, \mathrm{KAlSi}_{3} \mathrm{O}_{8}$ and $\mathrm{SiO}_{2}$ are shown in Fig. 2. 
Table 4. Margules-type excess parameters used in this study

\begin{tabular}{|c|c|c|c|c|}
\hline $\begin{array}{l}\text { Ab-Kfs Feldspar, } \\
\text { Elkins and Grove } \\
(1990)^{\mathrm{a}}\end{array}$ & & $W_{H}$ & $\mathrm{~W}_{S}$ & $\mathrm{w}_{V}$ \\
\hline 112 & & 18810 & 10.30 & 0.4602 \\
\hline 122 & & 27320 & 10.30 & 0.3264 \\
\hline $\begin{array}{l}\text { Melt, } \\
\text { this study }\end{array}$ & $W_{1112}$ & $W_{1122}$ & $W_{1222}$ & $k$ \\
\hline$a b-q t z$ & 25503.980 & -17245.030 & 8673.084 & 2 \\
\hline or-qtz & 8622.563 & -5946.898 & -7150.107 & 2 \\
\hline$a b-o r$ & 13969.360 & -30153.510 & 6921.565 & 2 \\
\hline $\mathrm{ab}-\mathrm{H}_{2} \mathrm{O}$ & -32471.070 & -21823.540 & -2926.132 & 2 \\
\hline or $-\mathrm{H}_{2} \mathrm{O}$ & -24849.790 & -14857.800 & 1723.691 & 2 \\
\hline $\mathrm{qtz}-\mathrm{H}_{2} \mathrm{O}$ & -27423.890 & 6269.606 & 9927.726 & -3 \\
\hline
\end{tabular}

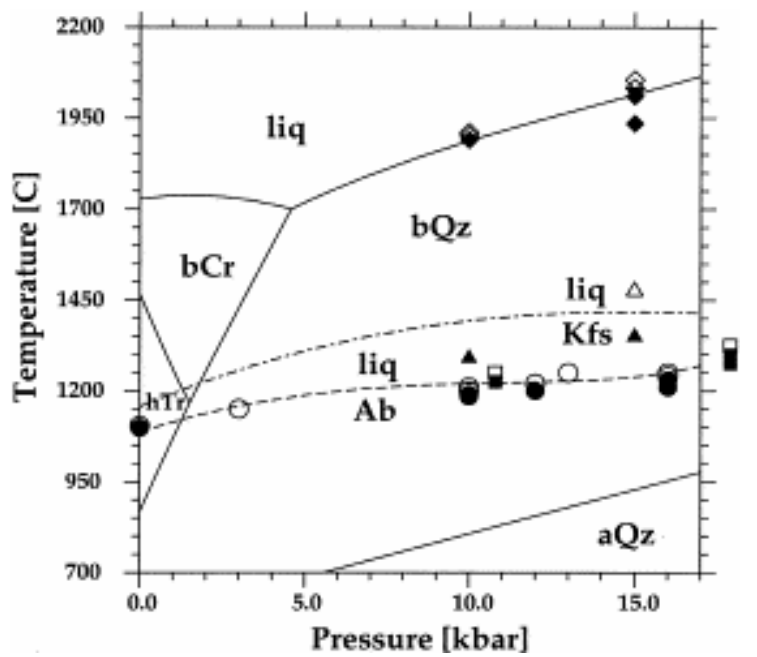

Fig. 2. Calculated fusion curves of $\mathrm{NaAlSi}_{3} \mathrm{O}_{8}, \mathrm{KAlSi}_{3} \mathrm{O}_{8}, \mathrm{Si}_{4} \mathrm{O}_{8}$. Calculated stability field boundaries of anhydrous $\mathrm{NaAlSi}_{3} \mathrm{O}_{8}$ (dashed line), $\mathrm{KAlSi}_{3} \mathrm{O}_{8}$ (dash-dotted line), $\mathrm{Si}_{4} \mathrm{O}_{8}$ (solid line) using Eq. (4) compared with experimental data. Open symbols denote liquid stable, solid symbols point crystalline phase stable; diamonds are from Hudon (1998), triangles from Lindsley (1966), circles from Boettcher et al. (1982), squares from Boyd and England (1963, not used in the optimization). Calculated Kfs melting is metastable with respect to incongruent melting to a liquid and leucite.

Fitted heats of fusion $\left(67.4 \mathrm{~kJ} / \mathrm{mol} \mathrm{NaAlSi}_{3} \mathrm{O}_{8}, 58.0 \mathrm{~kJ} / \mathrm{mol} \mathrm{KAlSi}_{3} \mathrm{O}_{8}, 35.6 \mathrm{~kJ} / \mathrm{mol} \mathrm{Si}_{4} \mathrm{O}_{8}\right)$ are close to reported values from Richet and Bottinga (1986) $(64.3 \pm 3,54.0 \pm 4,35.7 \pm 1 \mathrm{~kJ} / \mathrm{mol}$, respectively). The fitted heat of mixing surface of the anhydrous melt is plotted in Fig. 3 . Calculated $G^{\mathrm{xs}}$ of ab-or and qtz-or liquid is close to zero; ab-qtz mixing shows a small positive deviation from an ideal solution. This is in rough agreement with solution calorimetry measurements of ab-or-qtz glasses indicating slightly positive heats of mixing for ab-qtz (Navrotsky et al., 1980), small positive and negative heats of mixing for or-qtz, and negative heats of mixing for ab-or (Hervig and Navrotsky, 1984). Fraser and Bottinga (1985) reported positive heats of mixing at or-rich composition from in-situ measurements at $1200-1600^{\circ} \mathrm{C}$. This indicates a small temperature dependency of $H^{\mathrm{mix}}$ in ab-or liquids, which is probably 
averaged by the $T$-independent $H^{\text {mix }}$ model in this study. However, the precision of the fitted enthalpies of the liquid feldspar endmembers is not better than $3 \mathrm{~kJ}$ due to the uncertainty of heat of fusion measurements and thermochemical data of the crystalline reference phases (see, e.g. Arnorsson and Stefansson, 1999, for a review and discussion).

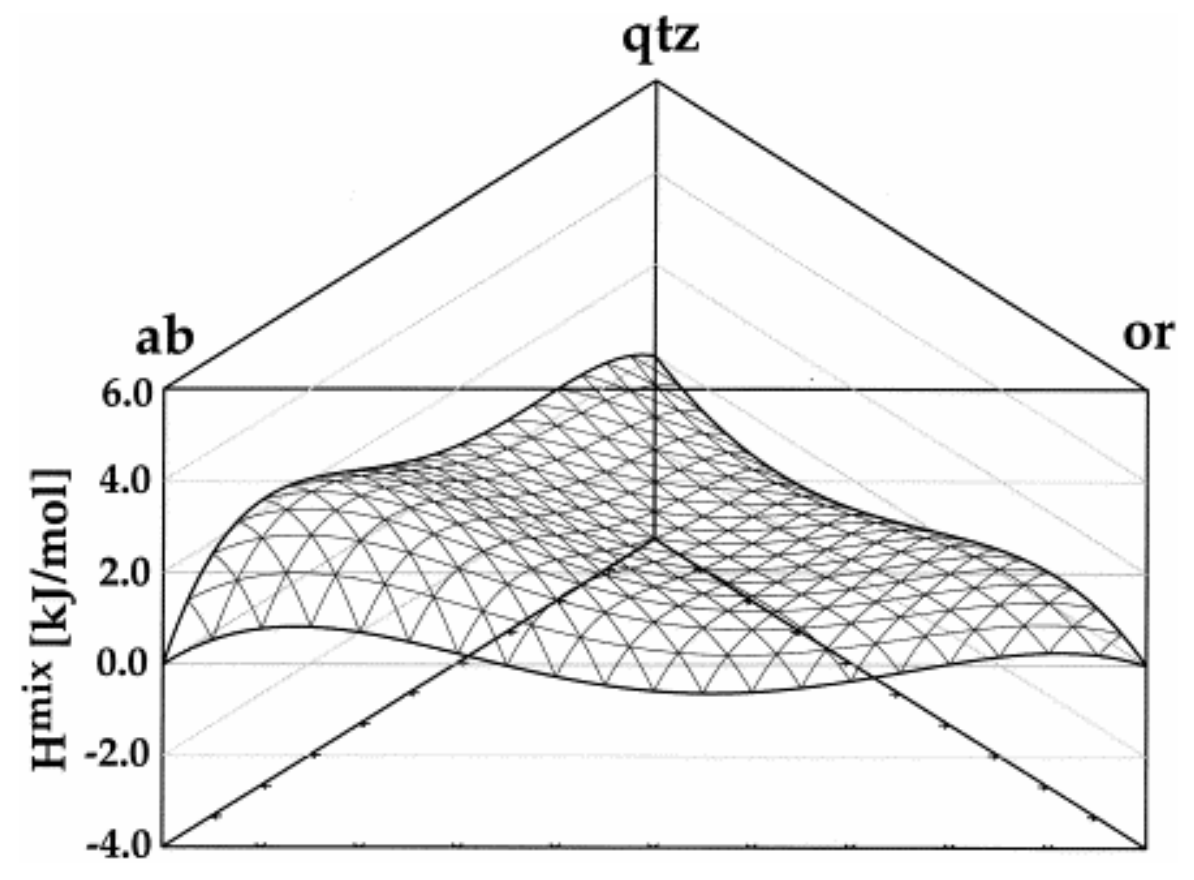

Fig. 3. Fitted $G^{\mathrm{xs}}$ surface of the anhydrous melt. Calculated $P, T$-independent $H^{\mathrm{mix}}$ surface of the anhydrous melt components shows small but complex departure from ideality.

Calculated isotherms of the liquidus surface in the system $\mathrm{NaAlSi}_{3} \mathrm{O}_{8}-\mathrm{KAlSi}_{3} \mathrm{O}_{8}-\mathrm{H}_{2} \mathrm{O}$ are shown in Fig. 4. Calculated phase relations at 2 and 5 kbars in the systems $\mathrm{NaAlSi}_{3} \mathrm{O}_{8}-\mathrm{Si}_{4} \mathrm{O}_{8}-$ $\mathrm{H}_{2} \mathrm{O}$ and $\mathrm{KAlSi}_{3} \mathrm{O}_{8}-\mathrm{Si}_{4} \mathrm{O}_{8}-\mathrm{H}_{2} \mathrm{O}$ are plotted in Fig. 5 and Fig. 6. Predicted crystal-liquid equilibria are in close agreement with experimental data at $\mathrm{H}_{2} \mathrm{O}$-saturated and -undersaturated conditions. However, the calculated liquid-fluid coexistence curve overestimates $\mathrm{H}_{2} \mathrm{O}$ solubility with increasing temperature due to neglect of melt dissolution.

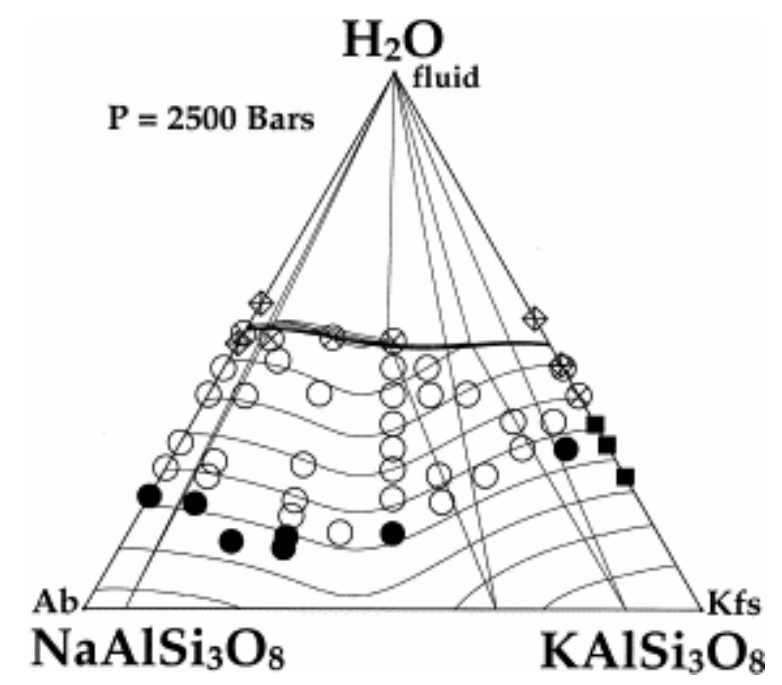

Fig. 4. Calculated isotherms on the liquidus surface in the system $\mathrm{NaAlSi}_{3} \mathrm{O}_{8}-\mathrm{KAlSi}_{3} \mathrm{O}_{8}-\mathrm{H}_{2} \mathrm{O}$ at 2500 bars, $800^{\circ} \mathrm{C}$ to $1200^{\circ} \mathrm{C}$ with $50^{\circ} \mathrm{C}$ increments, from this study compared with results from quench experiments at $1000 \pm 10^{\circ} \mathrm{C}$ (Fenn, 1973). Solid circles are quench of liquid+feldspar, open symbols point one liquid, slashed 
circles are liquid+fluid. Slashed diamonds are solubility data from Behrens et al. (2000) at 2 and $3 \mathrm{kbars}, 1000^{\circ} \mathrm{C}$ (ab) and $1200^{\circ} \mathrm{C}$ (or), respectively. Leucite stability field (solid squares) is omitted.

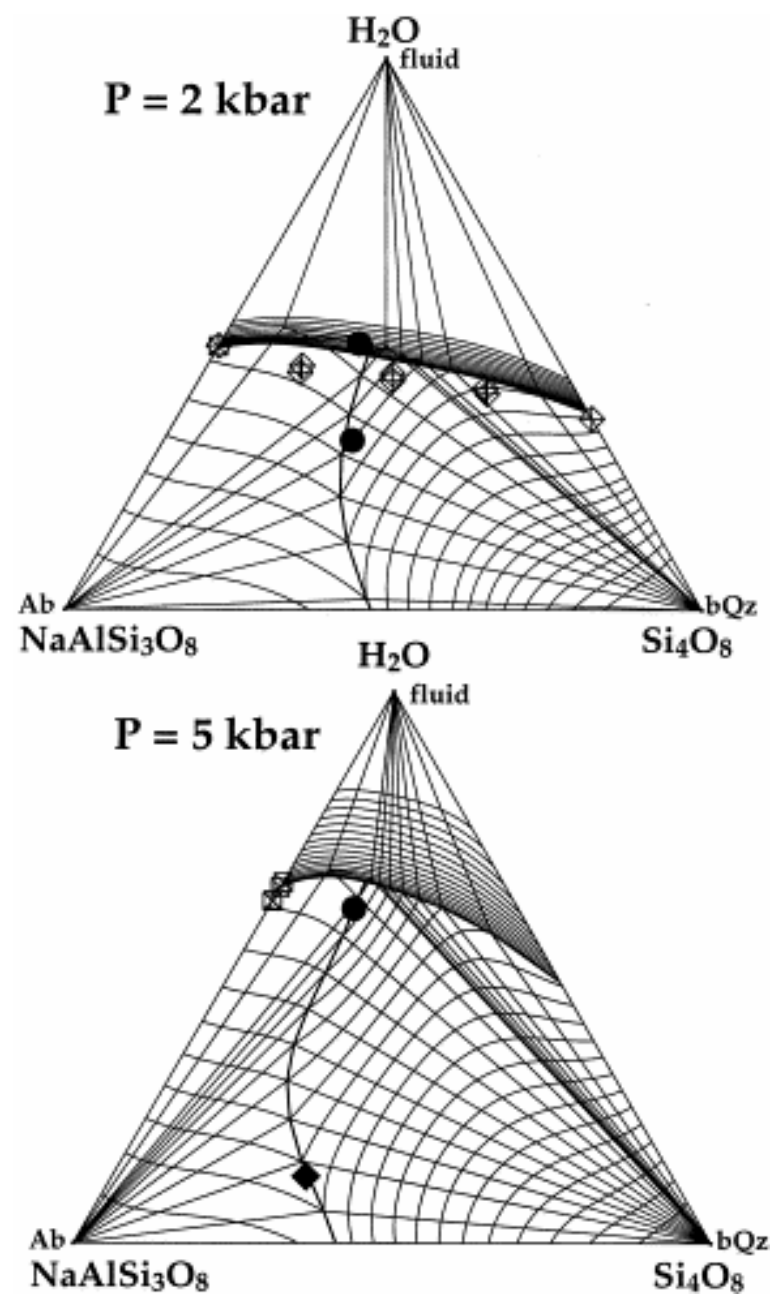

Fig. 5. Calculated isotherms on the liquidus surface in the system $\mathrm{NaAlSi}_{3} \mathrm{O}_{8}-\mathrm{Si}_{4} \mathrm{O}_{8}-\mathrm{H}_{2} \mathrm{O}$ at 2 and $5 \mathrm{kbars}, 700^{\circ} \mathrm{C}$ to $1700^{\circ} \mathrm{C}$ with $50^{\circ} \mathrm{C}$ increments. Solid symbols denote measured compositions of minimum melting at $\mathrm{H}_{2} \mathrm{O}$ saturated and -undersaturated conditions from Pichavant et al. $(1992) ; 680^{\circ} \mathrm{C}, 740^{\circ} \mathrm{C}, 860^{\circ} \mathrm{C}$, circles and Becker et al. (1998); $1095 \pm 10^{\circ} \mathrm{C}$, diamond. Open diamonds are measured $\mathrm{H}_{2} \mathrm{O}$ solubility at $1200^{\circ} \mathrm{C}$ and $1300^{\circ} \mathrm{C}$ ( $\mathrm{Holtz}$ et al., 2000). Squares are solubility data at $825^{\circ} \mathrm{C}, 2$ kbars and $860^{\circ} \mathrm{C}$ to $1200^{\circ} \mathrm{C}, 5 \mathrm{kbars}$ from Behrens et al. (2000). 


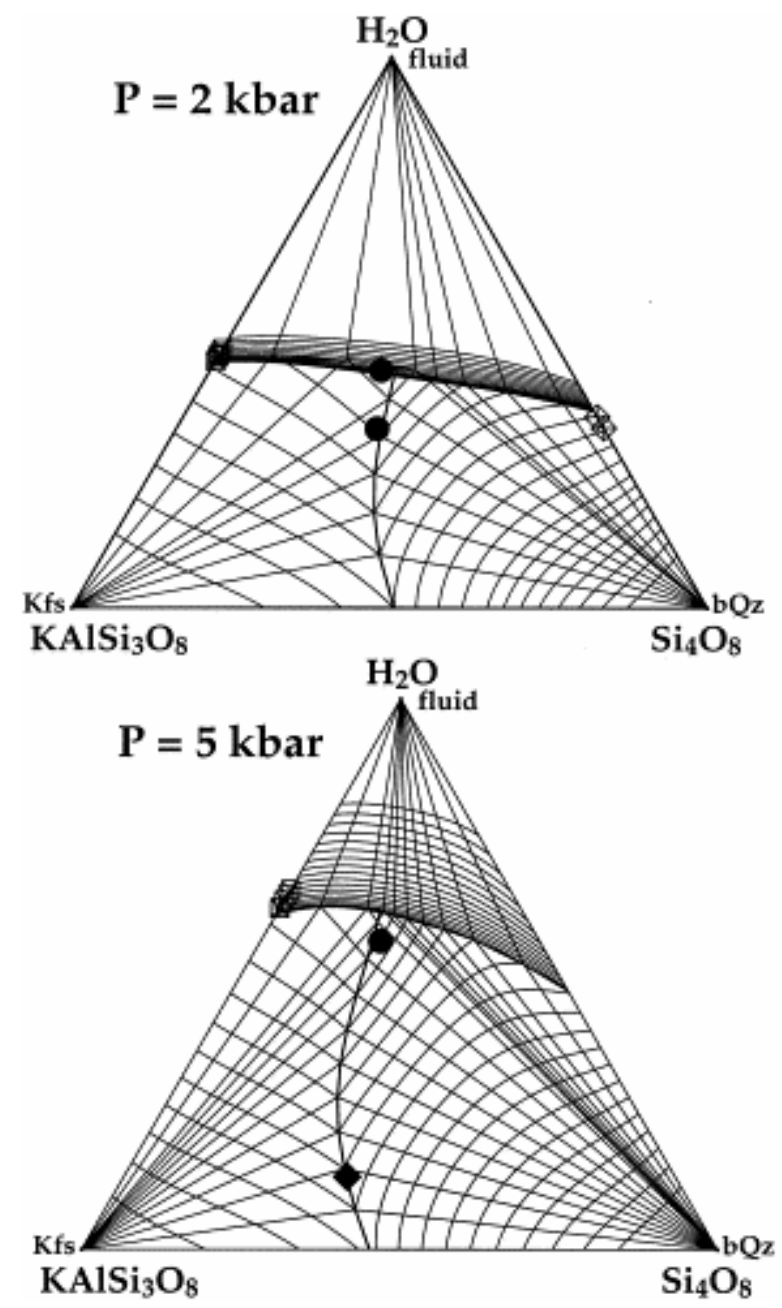

Fig. 6. Calculated isotherms on the liquidus surface in the system $\mathrm{KAlSi}_{3} \mathrm{O}_{8}-\mathrm{Si}_{4} \mathrm{O}_{8}-\mathrm{H}_{2} \mathrm{O}$ at 2 and 5 kbars, $700^{\circ} \mathrm{C}$ to $1700^{\circ} \mathrm{C}$ with $50^{\circ} \mathrm{C}$ increments. Solid symbols denote measured compositions of minimum melting at $\mathrm{H}_{2} \mathrm{O}$ saturated and -undersaturated conditions from Pichavant et al. (1992); $720^{\circ} \mathrm{C}, 750^{\circ} \mathrm{C}, 835^{\circ} \mathrm{C}$, circles and Becker et al. (1998); $1030 \pm 10^{\circ} \mathrm{C}$, diamond. Open diamonds are measured $\mathrm{H}_{2} \mathrm{O}$ solubility at $1200^{\circ} \mathrm{C}$ and $1300^{\circ} \mathrm{C}$ (Holtz et al., 2000). Squares are solubility data at $1000^{\circ} \mathrm{C}, 2 \mathrm{kbars}$ and $900^{\circ} \mathrm{C}$ to $1200^{\circ} \mathrm{C}, 5 \mathrm{kbars}$ from Behrens et al. (2000).

Exothermic heats of mixing were fitted in the ab- $\mathrm{H}_{2} \mathrm{O}$ and or $-\mathrm{H}_{2} \mathrm{O}$ systems at waterundersaturated compositions; qtz- $\mathrm{H}_{2} \mathrm{O}$ mixing is more complex containing a considerable positive excess term. This is consistent with observations in earlier studies, e.g. Shaw (1964), Clemens and Navrotsky (1987), Blencoe (1992) and Ghiorso and Sack (1995). The positive excess heat of mixing leads to a considerable metastable miscibility gap of the $\mathrm{SiO}_{2}-\mathrm{H}_{2} \mathrm{O}$ liquid at high $\mathrm{H}_{2} \mathrm{O}$ composition. We found a $T$-independent excess function adequate to describe experimental data within experimental uncertainty in the system $\mathrm{ab}-\mathrm{H}_{2} \mathrm{O}$ at $2.5 \mathrm{kbar}$ (Fenn, 1973) (see Fig. 1). Fitted absolute $\mathrm{ab}-\mathrm{H}_{2} \mathrm{O}$ excess heat of mixing is less than measured by Clemens and Navrotsky (1987). The calculated minimum at $x_{\mathrm{H} 2 \mathrm{O}}=0.32$ is in reasonable agreement with their estimate $(0.27)$. The remaining discrepancy can be reduced by assuming a $T$-dependent $G^{\mathrm{xs}}$ as suggested by Blencoe (1992), e.g. $W=W_{H}-T W_{S}+\left[T-T_{0}-T \ln \left(T / T_{0}\right)\right] W_{\mathrm{Cp}}$. However, small positive excess entropy $\left(W_{S}\right)$ or negative excess heat capacity $\left(W_{\mathrm{Cp}}\right)$ parameters were not included in the present formulation of $H^{\text {mix }}$, because they are not needed to fit experimental liquidus phase equilibrium data to $1100^{\circ} \mathrm{C}$. A small negative $C_{\mathrm{p}}{ }^{\mathrm{xs}}$ indicates 
that $C_{\mathrm{pH} 2 \mathrm{O} \text {,liq }}$ is slightly underestimated with $C_{\mathrm{pH} 2 \mathrm{O} \text {,glass }}$ (Richet, 1987) when extrapolated beyond the glass transition.

Using a Kohler extrapolation for the $\mathrm{Si}_{4} \mathrm{O}_{8}-\mathrm{H}_{2} \mathrm{O}$ excess function $(k=2)$ the calculated stability field of $\beta$-Qz was strongly inconsistent with experiments from Holtz et al. (1992b), Pichavant et al. (1992), and Becker et al. (1998). A positive $\mathrm{Si}_{4} \mathrm{O}_{8}-\mathrm{H}_{2} \mathrm{O}$ excess function at $x_{\mathrm{H} 2 \mathrm{O}}>0.58$ increases the free energy of mixing of the melt when extrapolated to the higher order system and, thus, leads to a larger calculated $\beta-\mathrm{Qz}$ stability field than measured at waterundersaturated compositions. In order to reduce the extrapolated $\mathrm{qtz}-\mathrm{H}_{2} \mathrm{O}$ contribution to $G^{\text {mix }}$ of the melt $k$ was set to -3 giving, indeed, a feasible region of the experimental qtz constraints. The use of $k=-3$ increases the polynomial degree of $G^{\mathrm{xs}}\left(\mathrm{qtz}-\mathrm{H}_{2} \mathrm{O}\right)$ from four to seven only for extrapolation purposes and leads to a strong decrease of the binary excess contribution in the higher order system, where $x_{\mathrm{qtz}}+x_{\mathrm{H} 2 \mathrm{O}}<1$. This suggests that (1) two distinct mixing mechanisms are attributed to feldspar $-\mathrm{H}_{2} \mathrm{O}$ and silica- $-\mathrm{H}_{2} \mathrm{O}$ melts and (2) the latter contributes to a very minor degree to the haplogranite system.

Experimentally determined liquidus phase relations from Holtz et al. (1992b) are in good agreement with predictions of the model of Burnham and Nekvasil (1986), revised in Nekvasil and Burnham (1987), for $\mathrm{H}_{2} \mathrm{O}$-saturated isobaric sections. However, the calculated $\beta-\mathrm{Qz}$ liquidus primary field increases with decreasing $a\left(\mathrm{H}_{2} \mathrm{O}\right)$ shifting the minimum liquidus composition towards the ab-or join in contrast to experimental data (Holtz et al., 1992b). At $\mathrm{H}_{2} \mathrm{O}$-undersaturated conditions $\mathrm{H}_{2} \mathrm{O}-\mathrm{qtz}$ mixing is approximated as an ideal Henryan solution: $a_{\mathrm{qtz}}\left(1-x_{\mathrm{H} 2 \mathrm{O}}\right)^{2}$ for $x_{\mathrm{H} 2 \mathrm{O}}<0.5$ (Burnham and Nekvasil, 1986; their Eq. 5). This relation is independent of the anhydrous composition, even if non-ideal mixing of the anhydrous components is considered with a separate term (Nekvasil and Burnham, 1987). We believe, that this formulation overestimates $a_{\mathrm{qtz}}$ when extrapolated to the haplogranite system in discrepancy with experiments. In this study, we used a polynomial of degree 7 for $G^{\mathrm{xs}}$ (qtz$\mathrm{H}_{2} \mathrm{O}$ ); its contribution to $a_{\mathrm{qtz}}$ decreases drastically in the multicomponent system.

MELTS incorporates a similar parametrization of the effect of water on magmatic phase equilibria (Ghiorso and Sack, 1995). Ghiorso and Sack (1995) included $\mathrm{H}_{2} \mathrm{O}$ as oxide component of the melt, with $\Delta_{\mathrm{f}} H^{0}=-280 \mathrm{~kJ} / \mathrm{mol}, S^{0}=152.6 \mathrm{~J} / \mathrm{K} \mathrm{mol}$ and a corrected $V(T, P)$ polynomial from Nicholls (1980) and refined regular solution parameters of the melt, i.e. $G^{\mathrm{xs}}=1 / 2 \sum_{i, j} W_{i j} x_{i} x_{j}$, using "anhydrous" and $\mathrm{H}_{2} \mathrm{O}$-saturated experimental liquidus data at magmatic compositions. We are aware that the merit of MELTS is the application to magmatic liquids. The projection of the thermodynamic model of the melt to bounding compositional subsystems outside the calibration range is not warranted as stated by Ghiorso and Sack (1995). Bearing this restriction in mind, the calculated liquidus temperatures and Fsp compositions using the public version MELTS-HP 2.0.4 yield an acceptable first-order approximation (within $10-60^{\circ} \mathrm{C}$ and $5 \mathrm{~mol} \%$ ) in the haplogranite system when compared to the experimental results at very low $\mathrm{H}_{2} \mathrm{O}$ activities from Becker et al. (1998). However, in all cases the calculated $\mathrm{SiO}_{2}$-saturation surface is at higher $\mathrm{SiO}_{2}$ content and lower temperature than observed and, regarding the experiments from Pichavant et al. (1992) and Holtz et al. (1992b), the difference between calculated and observed liquidus temperatures increases systematically (to $110^{\circ} \mathrm{C}$ ) with increasing $\mathrm{H}_{2} \mathrm{O}$ content and decreasing temperature. This indicates that an overestimated absolute $\mu_{\mathrm{H} 2 \mathrm{O}}{ }^{0}$ is compensated with the $\mathrm{H}_{2} \mathrm{O}$ melt excess parameters $W_{i j}$ when fitted to multicomponent data in $\mathrm{H}_{2} \mathrm{O}$-saturated systems. However, direct comparison of the fitted free energy of mixing surface is difficult due to the different choice of anhydrous melt endmember compositions. 


\section{Conclusions}

(1) We expanded the Margules approach as applied to $\mathrm{NaAlSi}_{3} \mathrm{O}_{8}-\mathrm{H}_{2} \mathrm{O}$ by Blencoe (1992) to hydrous haplogranite melts. Applying mathematical programming techniques, internally consistent thermochemical data for the hydrous melt have been derived from experimental phase equilibrium data. Using both experimental liquidus and solubility data and a simple approximation of the liquid molar volume, standard state thermochemical properties of the hypothetical $\mathrm{H}_{2} \mathrm{O}$ melt oxide component were estimated close to $\Delta_{\mathrm{f}} H^{0}=-287 \mathrm{~kJ} / \mathrm{mol}$ and $S^{0}=67.2 \mathrm{~J} / \mathrm{K} \mathrm{mol}$, respectively. Fitted $(\partial V / \partial T)_{P}$ and $(\partial V / \partial P)_{T}$ parameters indicate extremely high thermal expansivity and compressibility of the $\mathrm{H}_{2} \mathrm{O}$ melt component as observed by Ochs and Lange (1997).

(2) Assuming $\mathrm{NaAlSi}_{3} \mathrm{O}_{8}, \mathrm{KAlSi}_{3} \mathrm{O}_{8}$ and $\mathrm{Si}_{4} \mathrm{O}_{8}$ as anhydrous melt components and using measured heats of fusion from Richet and Bottinga (1986), we found a small, but complex excess heat of mixing necessary to reproduce reported liquidus phase equilibria.

(3) Thermodynamic assessment of phase equilibrium data from Holtz et al. (1992b), Pichavant et al. (1992) and Becker et al. (1998) suggests that two mixing mechanisms can be attributed to feldspar $-\mathrm{H}_{2} \mathrm{O}$ and qtz $-\mathrm{H}_{2} \mathrm{O}$ melts. Enthalpies of mixing of feldspar $-\mathrm{H}_{2} \mathrm{O}$ are negative to $x\left(\mathrm{H}_{2} \mathrm{O}\right)=0.9$ (or) and $1.0(\mathrm{ab})$, while qtz $-\mathrm{H}_{2} \mathrm{O}$ mixing displays positive excess contributions at $x\left(\mathrm{H}_{2} \mathrm{O}\right)>0.58$. The latter contributes to a very minor degree to the haplogranite system.

\section{Acknowledgements}

C. DeCapitani wrote the initial version of the optimization routine. We thank H. Nekvasil for generously providing us with her EQUIL90 source code. H. Behrens, F. Holtz and P. Hudon communicated experimental data prior to publication. Helpful comments from P. Asimov and C. Romano on an earlier draft of the manuscript are appreciated. This work was financially supported by the EC-TMR network "In-situ Hydrous Melts" (contract no. ERBFMRXCT960063).

\section{References}

Bai, T.B. and Koster van Groos, A.F., 1999. The distribution of Na, K, Rb, Sr, Al, Ge, Cu, W, $\mathrm{Mo}, \mathrm{La}$, and $\mathrm{Ce}$ between granitic melts and coexisting aqueous fluids. Geochim. Cosmochim. Acta 63, pp. 1117-1131.

Becker, A., Holtz, F. and Johannes, W., 1998. Liquidus temperatures and phase compositions in the system Qz-Ab-Or at $5 \mathrm{kbar}$ and very low water activities. Contrib. Mineral. Petrol. 130, pp. 213-224.

Behrens, H., 1995. Determination of water solubilities in high-viscosity melts: an experimental study on $\mathrm{NaAlSi}_{3} \mathrm{O}_{8}$ and $\mathrm{KAlSi}_{3} \mathrm{O}_{8}$ melts. Eur. J. Mineral. 7, pp. 905-920.

Behrens, H., Romano, C., Nowak, M., Holtz, F. and Dingwell, D.B., 1996. Near-infrared spectroscopic determination of water species of the system $\mathrm{MAlSi}_{3} \mathrm{O}_{8}(\mathrm{M}=\mathrm{Li}, \mathrm{Na}, \mathrm{K})$ : an interlaboratory study. Chem. Geol. 128, pp. 41-63. 
Behrens, H., Meyer, M., Benne, D., Nowak, M. and Holtz, F., 2000. Temperature and pressure dependence of water solubility in melts of $\mathrm{MAlSi}_{3} \mathrm{O}_{8}(\mathrm{M}=\mathrm{Li}, \mathrm{Na}, \mathrm{K}, \mathrm{Rb})$ endmember compositions. Chem. Geol. submitted.

Berman, R.G., 1988. Internally consistent thermodynamic data for minerals in the system $\mathrm{Na}_{2} \mathrm{O}-\mathrm{K}_{2} \mathrm{O}-\mathrm{CaO}-\mathrm{MgO}-\mathrm{FeO}-\mathrm{Fe}_{2} \mathrm{O}_{3}-\mathrm{Al}_{2} \mathrm{O}_{3}-\mathrm{SiO}_{2}-\mathrm{TiO}_{2}-\mathrm{H}_{2} \mathrm{O}-\mathrm{CO}_{2}$. J. Petrol. 29, pp. 445522.

Berman, R.G. and Brown, T.H., 1984. A thermodynamic model for multicomponent melts with application to the system $\mathrm{CaO}-\mathrm{Al}_{2} \mathrm{O}_{3}-\mathrm{SiO}_{2}$. Geochim. Cosmochim. Acta 48, pp. 661678 .

Berman, R.G. and Brown, T.H., 1985. Heat capacities of minerals in the system $\mathrm{Na}_{2} \mathrm{O}-\mathrm{K}_{2} \mathrm{O}-$ $\mathrm{CaO}-\mathrm{MgO}-\mathrm{FeO}-\mathrm{Fe}_{2} \mathrm{O}_{3}-\mathrm{Al}_{2} \mathrm{O}_{3}-\mathrm{SiO}_{2}-\mathrm{TiO}_{2}-\mathrm{H}_{2} \mathrm{O}-\mathrm{CO}_{2}$ : representation, estimation, and high temperature extrapolation. Contrib. Mineral. Petrol. 89, pp. 168-183.

Berman, R.G. and Brown, T.H., 1986. Erratum: heat capacities of minerals in the system $\mathrm{Na}_{2} \mathrm{O}-\mathrm{K}_{2} \mathrm{O}-\mathrm{CaO}-\mathrm{MgO}-\mathrm{FeO}-\mathrm{Fe}_{2} \mathrm{O}_{3}-\mathrm{Al}_{2} \mathrm{O}_{3}-\mathrm{SiO}_{2}-\mathrm{TiO}_{2}-\mathrm{H}_{2} \mathrm{O}-\mathrm{CO}_{2}$ : representation, estimation, and high temperature extrapolation. Contrib. Mineral. Petrol. 94, p. 262.

Berman, R.G., Engi, M., Greenwood, H.J. and Brown, T.H., 1986. Derivation of internally consistent thermodynamic data by the technique of mathematical programming: a review with application to the system $\mathrm{MgO}-\mathrm{SiO}_{2}-\mathrm{H}_{2} \mathrm{O}$. J. Petrol. 27, pp. 1331-1364.

Berman, R.G. and Aranovich, L.Y., 1996. Optimized standard state and solution properties of minerals: I. Model calibration for olivine, orthopyroxene, cordierite, and ilmenite in the system FeO-MgO-CaO- $\mathrm{H}_{2} \mathrm{O}$. Contrib. Mineral. Petrol. 126, pp. 1-24.

Blencoe, J.G., 1992. A two-parameter Margules method for modelling the thermodynamic mixing properties of albite-water melts. Trans. R. Soc. Edingburgh: Earth Sci. 83, pp. 423428.

Boettcher, A., Burnham, C., Windom, K. and Bohlen, S., 1982. Liquids, glasses, and the melting of silicates to high pressures. J. Geol. 90, pp. 127-138.

Boettcher, A., Guo, Q., Bohlen, S. and Hanson, B., 1984. Melting in feldspar-bearing systems to high pressures and structures of aluminosilicate liquids. Geology 12, pp. 202-204.

Boyd, F.R. and England, J.L., 1963. Effect of pressure on the melting of diopside $\mathrm{CaMgSi}_{2} \mathrm{O}_{8}$ and albite $\mathrm{NaAlSi}_{3} \mathrm{O}_{8}$ in the range up to 50 kilobars. J. Geophys. Res. 68, pp. 311-323.

Bowen, N.L. and Tuttle, O.F., 1950. The system $\mathrm{NaAlSi}_{3} \mathrm{O}_{8}-\mathrm{KAlSi}_{3} \mathrm{O}_{8}-\mathrm{H}_{2}$ O. J. Geol. 58, pp. 489-511.

Burnham, C.W., 1974. $\mathrm{NaAlSi}_{3} \mathrm{O}_{8}-\mathrm{H}_{2} \mathrm{O}$ solutions: a thermodynamic model for hydrous silicate magmas. Bull. Soc. Fr. Mineral. Cristallogr. 97, pp. 223-230.

Burnham, C.W. and Davis, N.F., 1971. The role of $\mathrm{H}_{2} \mathrm{O}$ in silicate melts: I. $P-V-T$ relations in the system $\mathrm{NaAlSi}_{3} \mathrm{O}_{8}-\mathrm{H}_{2} \mathrm{O}$ to 10 kilobars and $1000^{\circ} \mathrm{C}$. Am. J. Sci. 270, pp. 54-79. 
Burnham, C.W. and Nekvasil, H., 1986. Equilibrium properties of granite pegmatite magmas. Am. Mineral. 71, pp. 239-263.

Clemens, J.D. and Navrotsky, A., 1987. Mixing properties of $\mathrm{NaAlSi}_{3} \mathrm{O}_{8}$ melt- $\mathrm{H}_{2} \mathrm{O}$ : new calorimetric data and some geological implications. Geochim. Cosmochim. Acta 95, pp. 173186.

DeCapitani, C. and Kirschen, M., 1998. A generalized multicomponent excess function with application to immiscible liquids in the system $\mathrm{CaO}-\mathrm{SiO}_{2}-\mathrm{TiO}_{2}$. Geochim. Cosmochim. Acta 62, pp. 3753-3763.

Elkins, L.T. and Grove, T.L., 1990. Ternary feldspar experiments and thermodynamic models. Am. Mineral. 75, pp. 544-559.

Fenn, P.M., 1973. Nucleation and growth of alkali feldspars from melts in the system $\mathrm{NaAlSi}_{3} \mathrm{O}_{8}-\mathrm{KAlSi}_{3} \mathrm{O}_{8}-\mathrm{H}_{2} \mathrm{O}$. PhD dissertation, Stanford University, $167 \mathrm{pp}$.

Fraser, D.G. and Bottinga, Y., 1985. The mixing properties of melts and glasses in the system $\mathrm{NaAlSi}_{3} \mathrm{O}_{8}-\mathrm{KAlSi}_{3} \mathrm{O}_{8}$ : comparison of experimental data obtained by Knudsen mass spectroscopy and solution calorimetry. Geochim. Cosmochim. Acta 49, pp. 1377-1381.

Ghiorso, M.S. and Sack, R.O., 1995. Chemical mass transfer in magmatic processes: IV. A revised and internally consistent thermodynamic model for the interpolation and extrapolation of liquid-solid equilibria in magmatic systems at elevated temperatures and pressures. Contrib. Mineral. Petrol. 119, pp. 197-212.

Goldsmith, J.R. and Jenkins, D.M., 1985. The hydrothermal melting of low and high albite. Am. Mineral. 70, pp. 924-933.

Goldsmith, J.R. and Peterson, J.W., 1990. The hydrothermal melting behaviour of $\mathrm{KAlSi}_{3} \mathrm{O}_{8}$ as microcline and sanidine. Am. Mineral. 75, pp. 1362-1469.

Goranson, R.W., 1931. The solubility of water in granite magmas. Am. J. Sci. 22, pp. 481502.

Goranson, R.W., 1932. Some notes on the melting of granite. Am. J. Sci. 23, pp. 227-236.

Gordon, T.M., 1973. Determination of internally consistent thermodynamic data from phase equilibrium experiments. J. Geol. 81, pp. 199-208.

Haar, L., Gallagher, J.S. and Kell, G.S., 1984. NBS/NRC Steam Tables: Thermodynamic and Transport Properties and Computer Programs for Vapor and Liquid States of Water in SI Units, Hemisphere Publishing.

Hervig, R.L. and Navrotsky, A., 1984. Thermochemical study of glasses in the system $\mathrm{NaAlSi}_{3} \mathrm{O}_{8}-\mathrm{KAlSi}_{3} \mathrm{O}_{8}-\mathrm{Si}_{4} \mathrm{O}_{8}$ and the join $\mathrm{Na}_{1.6} \mathrm{Al}_{1.6} \mathrm{Si}_{2.4} \mathrm{O}_{8}-\mathrm{K}_{1.6} \mathrm{Al}_{1.6} \mathrm{Si}_{2.4} \mathrm{O}_{8}$. Geochim. Cosmochim. Acta 48, pp. 513-522.

Holtz, F., Behrens, H., Dingwell, D. and Johannes, W., 1995. $\mathrm{H}_{2} \mathrm{O}$ solubility in haplogranitic melts: compositional, pressure, and temperature dependence. Am. Mineral. 80, pp. 94-108. 
Holtz, F., Behrens, H., Dingwell, D. and Taylor, R.P., 1992. Water solubility in aluminosilicate melts of haplogranite composition at 2 kbar. Chem. Geol. 96, pp. 289-302. Abstract

Holtz, F., Pichavant, M., Barbey, P. and Johannes, W., 1992. Effects of $\mathrm{H}_{2} \mathrm{O}$ on liquidus phase relations in the haplogranite system at 2 and 5 kbar. Am. Mineral. 77, pp. 1223-1241.

Holtz, F., Roux, J., Behrens, H. and Pichavant, M., 2000. Water solubility in silica and quartzofeldspathoic aluminosilicate melts. Eur. J. Mineral. 85, pp. 682-686.

Hudon, P., 1998. The study of melts in the ternary $\mathrm{CaO}-\mathrm{MgO}-\mathrm{SiO}_{2}$ at high pressure and the nature of immiscibility in binary systems. PhD Thesis, McGill University, Montreal, 362 pp.

Hudon, P., Baker, D. and Toft, P.B., 1994. A high-temperature assembly for 1.91-cm (3/4") piston-cylinder apparatus. Am Mineral. 79, pp. 145-147.

Jackson, I., 1976. Melting of silica isotypes $\mathrm{SiO}_{2}, \mathrm{BeF}_{2}$ and $\mathrm{GeO}_{2}$ at elevated pressures. Phys. Earth Planet. Inter. 13, pp. 218-231.

Kennedy, G.C., Wasserburg, G.J., Heard, H.C. and Newton, R.C., 1962. The upper threephase region in the system $\mathrm{SiO}_{2}-\mathrm{H}_{2} \mathrm{O}$. Am. J. Sci. 260, pp. 501-521.

Knoche, R., Dingwell, D.B. and Webb, S.L., 1995. Melt densities for leucogranites and granitic pegmatites: partial molar volumes for $\mathrm{Al}_{2} \mathrm{O}_{3}, \mathrm{Na}_{2} \mathrm{O}, \mathrm{K}_{2} \mathrm{O}, \mathrm{Li}_{2} \mathrm{O}, \mathrm{Rb}_{2} \mathrm{O}, \mathrm{Cs}_{2} \mathrm{O}, \mathrm{MgO}$, $\mathrm{CaO}, \mathrm{SrO}, \mathrm{BaO}, \mathrm{B}_{2} \mathrm{O}_{3}, \mathrm{P}_{2} \mathrm{O}_{5}, \mathrm{~F}_{2} \mathrm{O}_{-1}, \mathrm{TiO}_{2}, \mathrm{Nb}_{2} \mathrm{O}_{5}, \mathrm{Ta}_{2} \mathrm{O}_{5}$, and $\mathrm{WO}_{3}$. Geochim. Cosmochim. Acta 59, pp. 4645-4652.

Kohler, F., 1960. Zur Berechnung der thermodynamischen Daten eines ternaeren Systems aus den zugehoerigen binaeren Systemen. Monatsh. Chem. 91, pp. 738-740.

Lindsley, D.H., 1966. Melting relations of $\mathrm{KAlSi}_{3} \mathrm{O}_{8}$ : effect of pressures up to 40 kilobars. Am. Mineral. 51, pp. 1793-1799.

Luth, W.C., Jahns, R.H. and Tuttle, O.F., 1964. The granite system at pressures of 4 to 10 kilobars. J. Geophys. Res. 69, pp. 759-773.

Murtagh, B.A., Saunders, M.A., 1998. MINOS 5.5. User's Guide (technical report SOL 8320R, revised). Systems Optimization Laboratory, Stanford University.

Navrotsky, A., Hon, R., Weill, D.F. and Henry, D.J., 1980. Thermochemistry of glasses and liquids in the systems $\mathrm{CaMgSi}_{2} \mathrm{O}_{6}-\mathrm{CaAl}_{2} \mathrm{Si}_{2} \mathrm{O}_{8}-\mathrm{NaAlSi}_{3} \mathrm{O}_{8}, \mathrm{CaAl}_{2} \mathrm{Si}_{2} \mathrm{O}_{8}-\mathrm{NaAlSi}_{3} \mathrm{O}_{8}$ and $\mathrm{SiO}_{2}-\mathrm{Al}_{2} \mathrm{O}_{3}-\mathrm{CaO}-\mathrm{Na}_{2} \mathrm{O}$. Geochim. Cosmochim. Acta 44, pp. 1409-1423.

Nekvasil, H. and Burnham, C.W., 1987. The calculated individual effects of pressure and water content on phase equilibria in the granite system. In: Mysen, B.O., Editor, , 1987. Magmatic Processes: Physicochemical Principles, The Geochemical Society, Pennsylvania, pp. 433-445.

Nicholls, J., 1980. A simple thermodynamic model for estimating the solubility of $\mathrm{H}_{2} \mathrm{O}$ in magmas. Contrib. Mineral. Petrol. 74, pp. 211-220. 
Ochs, F.A.I. and Lange, R.A., 1997. The partial molar volume, thermal expansivity, and compressibility of $\mathrm{H}_{2} \mathrm{O}$ in $\mathrm{NaAlSi}_{3} \mathrm{O}_{8}$ liquid: new measurements and an internally consistent model. Contrib. Mineral. Petrol. 129, pp. 155-165.

Pichavant, M., Holtz, F. and McMillan, P., 1992. Phase relations and compositional dependence of $\mathrm{H}_{2} \mathrm{O}$ solubility in quartz-feldspar melts. Chem. Geol. 96, pp. 303-319.

Powell, R. and Holland, T., 1993. The applicability of least squares in the extraction of thermodynamic data from experimentally bracketed mineral equilibria. Am. Mineral. 78, pp. $107-112$.

Richet, P., 1987. Heat capacity of silicate glasses. Chem. Geol. 62, pp. 111-127.

Richet, P. and Bottinga, Y., 1984. Glass transitions and thermodynamic properties of amorphous $\mathrm{SiO}_{2}, \mathrm{NaAlSi}_{n} \mathrm{O}_{(2 n+2)}$ and $\mathrm{KAlSi}_{3} \mathrm{O}_{8}$. Geochim. Cosmochim. Acta 48, pp. 453-470.

Richet, P. and Bottinga, Y., 1986. Thermochemical properties of silicate glasses and liquids: a review. Rev. Geophys. 24, pp. 1-25.

Richet, P. and Polian, A., 1998. Water as a dense icelike component in silicate glasses. Science 281, pp. 396-398.

Salje, E., 1985. Thermodynamics of soldium feldspar: II. Experimental results and numerical calculations. Phys. Chem. Miner. 12, pp. 99-107.

Shaw, H.R., 1964. Theoretical solubility of $\mathrm{H}_{2} \mathrm{O}$ in silicate melts - quasi-crystalline models. J. Geol. 72, pp. 601-617.

Shen, A. and Keppler, H., 1997. Direct observation of complete miscibility in the albite- $\mathrm{H}_{2} \mathrm{O}$ system. Nature 385, pp. 710-712.

Steiner, J.C., 1970. An experimental study of the assemblage alkali feldspar+liquid+quartz in the system $\mathrm{NaAlSi}_{3} \mathrm{O}_{8}-\mathrm{KAlSi}_{3} \mathrm{O}_{8}-\mathrm{SiO}_{2}-\mathrm{H}_{2} \mathrm{O}$ at 4000 bars. $\mathrm{PhD}$ dissertation, Stanford University, $98 \mathrm{pp}$.

Tuttle, O.F. and Bowen, N.L., 1958. Origin of granite in the light of experimental studies in the system $\mathrm{NaAlSi}_{3} \mathrm{O}_{8}-\mathrm{KAlSi}_{3} \mathrm{O}_{8}-\mathrm{SiO}_{2}-\mathrm{H}_{2} \mathrm{O}$. Geol. Soc. Am. Bull. 74145 pp.

Wen, S. and Nekvasil, H., 1994. Ideal associated solutions: application to the system albitequartz- $\mathrm{H}_{2} \mathrm{O}$. Am. Mineral. 79, pp. 316-331. 